JURNAL Midwifery Update (MU)

http://jurnalmu.poltekkes-mataram.ac.id/index.php/jurnalmu

e-ISSN: 2684-8511 (Online)

\title{
HUBUNGAN PERILAKU STIMULASI MOTORIK OLEH ORANG TUA DENGAN PERKEMBANGAN BAHASA ANAK USIA 12-36 BULAN
}

\author{
Susanti Tria Jaya ${ }^{1}$, Nurin Fauziyah ${ }^{2}$, Ratih Kusuma $\mathbf{W}^{3}$ \\ 1, 2, 3 Prodi Kebidanan, STIKes Pamenang, Pare, Kediri, Indonesia
}

\begin{abstract}
Abstrak
Masalah yang muncul dimasyarakat Indonesia adalah 30,56\% kurangnya perhatian atau perilaku dari orang tua tentang memberikan stimulasi motorik terhadap tumbuh kembang anaknya terutama pada perkembangan bahasa anak. Tujuan penelitian ini adalah untuk mengetahui hubungan perilaku stimulasi motorik oleh orangtua dengan perkembangan bahasa anak usia 12-36 bulan di Desa Merjoyo Kecamatan Purwoasri Kabupaten Kediri Tahun 2018. Desain penelitian menggunakan desain penelitian analitik korelasional dengan pendekatan cross sectional. Sampel yang diteliti adalah sebagian orang tua di Desa Merjoyo Kecamatan Purwoasri Kabupaten Kediri yang memiliki anak usia 12-36 bulan sebanyak 67 orang. Teknik sampling yang digunakan dalam penelitian ini adalah tehnik simple random sampling. Pengukuran data untuk perilaku Stimulasi Motorik oleh orang tua menggunakan kuesioner dan perkembangan bahasa menggunakan KPSP(Kuesioner Pre Skreening Perkembangan) yang kemudian diuji statistik menggunakan rank spearman correlation. Hasil penelitian yang dilakukan di Desa Merjoyo Kecamatan Purwoasri Kabupaten Kediri Tahun 2018 menunjukkan perilaku Stimulasi Motorik motorik oleh orang tua yang sangat baik yaitu sebanyak 37 responden (55,22\%), baik 21 responden $(31,3 \%)$ dan cukup sebanyak 9 responden (13,43\%), serta perkembangan bahasa anak usia 12-36 bulan yang sesuaiyaitu 48 responden $(71,6 \%)$, meragukan 14 responden $(20,9 \%)$ dan menyimpang 5 responden $(7,5 \%)$. Hubungan antara perilaku Stimulasi Motorik oleh orangtua dengan perkembangan bahasa anak usia 12-36 bulan yang berisi $r=0,730$ dengan uji signifikan $(\mathrm{p})=0,000$ dan tingkat kesalahan $(\alpha) 5 \%=0,05$. Dengan demikian $\mathrm{p}<\alpha$ maka Ho ditolak sedangkan H1 diterima, berarti ada hubungan positif dan tingkat hubungan yang kuat.Berdasarkan hasil penelitian direkomendasikan orang tua mampu menerapkan pengetahuan yang didapatkan kepada anaknya,bidan melakukan pendekatan dengan memberikan penyuluhan tentang perilaku Stimulasi Motorik yang sesuai dan karya tulis ini sebagai bahan penelitian selanjutnya serta dapat membantu desa menjadi lebih baik dalam mengoptimalkan tumbuh kembang anak.
\end{abstract}

Kata Kunci : Perilaku, Stimulasi Motorik, Perkembangan Bahasa

\section{THE RELATIONSHIP BETWEEN BEHAVIOR OF PARENTS MOTOR STIMULATION WITH LANGUAGE DEVELOPMENT OF CHILDREN'S 12-36 MONTHS}

\begin{abstract}
Problem that appear to socialized indonesia 30,56\% attention undercommunication or behaviour from parents about give stimulation towards grow the child flower especially in child language development. This watchfulness aim detects stimulation behaviour connection by parents with age child language development 12-36 month at village merjoyo district purwoasri regency kediri year 2018. Watchfulness design uses correlation design with approach survey analytic with approach cross sectional. sample that canvassed old some people that has age child 12-36 month as much as 67person. Technics sampling that used in this watchfulness technics simple random sampling. data measurement for stimulation behaviour by parents uses kuesioner and language development uses KPSP (Kuesioner Pre Skreening Perkembangan) then tested statistics uses rank spearman correlation. Watchfulness result that done at village merjoyo district purwoasri regency kediri year 2018 show stimulation behaviour by parents very good that is as much as 37 respondents $(55,22 \%)$, baik 21 respondents $(31,3 \%)$ dan enough as much as 9 respondents $(13,43 \%$, with age child language development 12-36 appropriate month that is 48 respondents (71,6\%), doubt 14 respondents (20,9\%) and deviate 5 respondents (7,5\%). Connection by parents with age child language development 12-36
\end{abstract}


monthcontaining $r=0,730$ with test significant $(p)=0,000$ and error level $(\alpha) 5 \%=0,05$. thereby $p<\alpha$ so ho aversed while hl accepted, mean there positive connection and strong connection level.Based on watchfulness result is recommended parents can to apply erudition that got to the child, midwife does to approach with give elucidation about the appropriate stimulation behaviour and work write this upon which watchfulness furthermore with can help village be better in optimize to grow child flower.

Key Words: Behaviour, Stimulation, Growth Language

\section{Pendahuluan}

Di Indonesia jumlah anak usia 12-36 bulan (masa Golden Period) sekitar 10\% dari seluruh populasi. Masalah yang muncul dimasyarakat Indonesia adalah $30,56 \%$ kurangnya perhatian atau perilaku dari orangtua tentang memberikan stimulasi motorik terhadap tumbuh kembang anaknya terutama pada perkembangan bahasa anak dan 17\% masalah anak - anak diantaranya 6,4\% kelemahan berbicara, 4,6\% kelemahan bicara dan bahasa, dan $6 \%$ kelemahan bahasa. ${ }^{1,2}$

Berdasarkan studi awal peneliti memperoleh temuan bahwa di Desa Merjoyo Kecamatan Purwoasri Kabupaten Kediri didapatkan 150 balita yang usia 12-36 bulan ada 80 anak. Setelah dilakukan wawancara tentang perkembangan bahasa kepada 10 orang tua yang mempunyai anak usia 12-36 bulan dengan kuesioner dan checklist didapatkan hasilnya dari perilaku stimulasi motorik halus orang tua mendapatkan nilai yang bagus rata-rata $80 \%$. Untuk yang perkembangan bahasa anak, 8 anak $(80 \%)$ diketahui mengalami keterlambatan perkembangan bahasa dan 2 anak (20\%) mengalami perkembangan bahasa sesuai umur.

Upaya yang harus dilakukan sebagai tenaga kesehatan terhadap perkembangan bahasa anak untuk menanggulangi masalah keterlambatan bicara anak yaitu mendeteksi dini mengenali keterlambatan bicara pada anak dan menstimulasi motorik sejak dini sangat penting bagi anak. Sebaliknya Orangtua juga memiliki peran penting dalam optimalisasi perkembangan seorang anak. Orangtua harus selalu memberikan rangsang atau stimulasi motorik kepada anak dalam aspek perkembangan bahasa. Stimulasi Motorik ini harus di berikan secara rutin dan berkesinambungan dengan kasih sayang, metode bermain dan lain-lain, sehingga perkembangan anak akan berjalan optimal. Kurangnya stimulasi motorik dari orang tua dapat mengakibatkan keterlambatan perkembangan anak, karena itu para orang tua harus diberi penjelasan cara melakukan Stimulasi Motorik kepadaanak. Berdasarkan latar belakang diatas maka peneliti tertarik untuk mengadakan penelitian yang berjudul "Hubungan Perilaku Stimulasi Motorik oleh Orang Tua dengan Perkembangan Bahasa Pada Anak Usia 12-36 bulan di Desa Merjoyo Kecamatan Purwoasri Kabupaten Kediri Tahun 2018.

\section{Metode}

Penelitian ini menggunakan desain penelitian analitik korelasional dengan pendekatan cross sectional. Berdasarkan tujuan penelitian, termasuk penelitian korelasi karena bertujuan mengetahui hubungan timbal balik antara satu variabel dengan variabel lain.Penelitian ini dilakukan pada tanggal 3 - 7 Juni 2018. Populasi yang diteliti adalah Semua orang tua yang mempunyai anak usia 12-36 bulan yang ada di Desa Merjoyo Kecamatan Purwoasri Kabupaten Kediri berjumlah 80 orang. Teknik sampling yang digunakan dalam penelitian ini adalah pengambilan sampel secara acak metode simple random sampling, yaitu sejumlah 67 orang.

Penelitian ini terdiri dari 2 variabel yaitu Variabel bebas dan terikat. Variable bebas dalam penelitian ini adalah perilaku Stimulasi Motorik motorik halus oleh orang tua terhadap anak usia 12-36 bulan, sedangkan variabel terikat adalah perkembangan bahasa anak usia 12-36 bulan.

Instrumen penelitian berupa kuesioner ini terdiri dari 20 pernyataan dan jenis kuesioner ini adalah kuesioner terbuka yang berisi jawaban Sangat Setuju (SS), Setuju (S), Tidak Setuju (TS), Sangat Tidak Setuju (STS). Instrumen yang dipakai dalam Variabel terikat yaitu perkembangan bahasa anak usia 12- 
36 bulan adalah dengan menggunakan KPSP (Kuesioner Pre Skreening Perkembangan) yang terdiri dari 10 pertanyaan untuk setiap 3 bulan pada anak usia 12-24 bulan dan 10 pertanyaan untuk setiap 6 bulan pada anak usia 24-36 bulan, dengan jawaban ya/tidak yang pertanyaan itu terjawab 9-10 adalah sesuai, 7-8 adalah meragukan dan 6 adalah menyimpang. Kemudian, data dianalaisis menggunakan uji statistik rank spearman correlation

\section{Hasil Penelitian dan Pembahasan}

\section{Hasil}

1. Data umum

a. Karakteristik respon den berdasarkan pendidikan terakhir orang tua

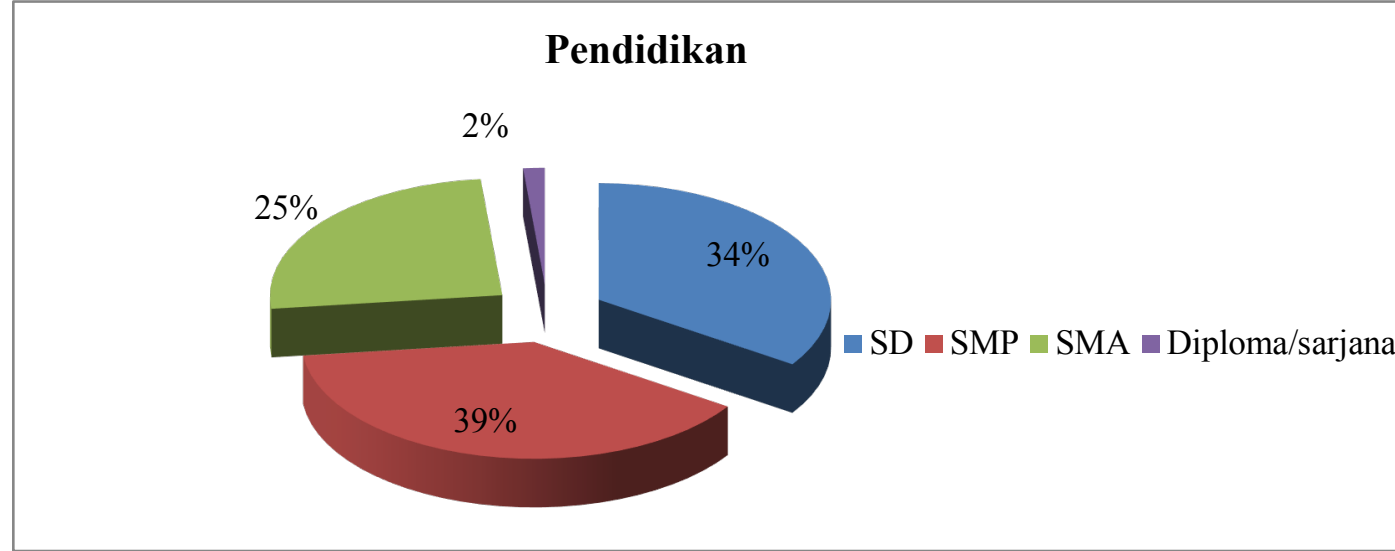

Gambar 1: Persentase responden berdasarkan pendidikan terakhir orang tua

Berdasarkan diagram di atas menunjukkan bahwa 67 responden sebagian besar berpendidikan SMP yaitu 26 responden (39\%), SD sebanyak 23 responden (34,3\%),SMA sebanyak 17 responden $(25,4 \%)$ dan PT sebanyak 1 responden $(2 \%)$.

b. Karakteristik responden berdasarkan umur orang tua

\section{Umur}

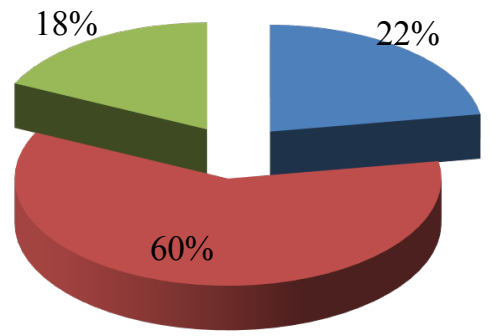

$\because<20$ th

-20-35 th

$>35$ th

Gambar 2: Persentase responden berdasarkan umur

Berdasarkan diagram di atas menunjukkan bahwa 67 responden sebagian besar berumur 20-35 tahun yaitu 40 responden $(60 \%)$, umur $<20$ tahun sebanyak 15 responden $(22,4 \%)$ dan umur $>35$ tahun sebanyak 12 responden (17\%). 
c. Karakteristik responden berdasarkan pekerjaan orang tua

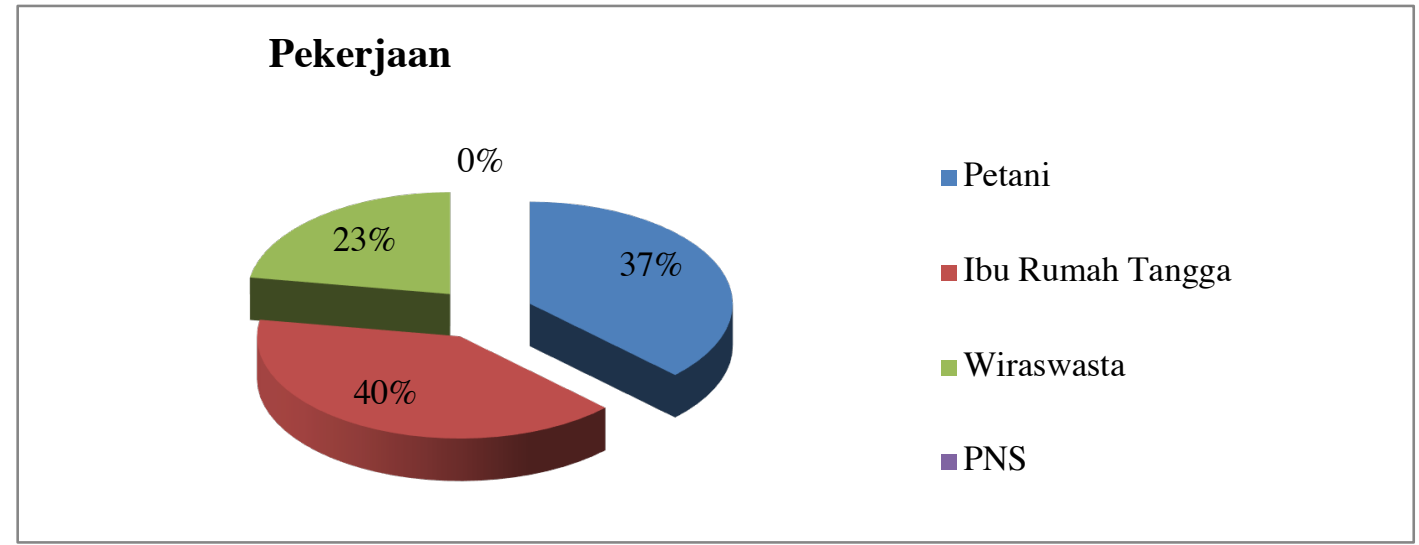

Gambar 3: Persentase responden berdasarkan pekerjaan

Berdasarkan tabel di atas menunjukkan bahwa 67 responden sebagian besar responden sebagai Ibu Rumah Tangga yaitu 27 responden (41\%), Petani sebanyak 25 responden (37,3\%), Wiraswasta sebanyak 15 responden $(22,4 \%)$ danPNS $(0 \%)$.

2. Data Khusus

a. Perilaku Stimulasi Motorik Oleh Orang Tua

Tabel 1: Distribusi Frekuensi Perilaku Stimulasi Motorik Oleh Orang Tua Pada Anak Usia 12-36 Bulan

\begin{tabular}{ccc}
\hline $\begin{array}{c}\text { Perilaku Stimulasi Motorik } \\
\text { Oleh Orang Tua }\end{array}$ & $\boldsymbol{F}$ & Persentase (\%) \\
\hline Sangat Baik & 37 & 55,22 \\
Baik & 21 & 31,34 \\
Cukup & 9 & 13,43 \\
Kurang & 0 & 0 \\
Jumlah & 67 & 100 \\
\hline
\end{tabular}

Berdasarkan tabel diatas perilaku Stimulasi Motorik oleh orang tua pada anak usia 12-36 bulan sebagian besar orang tua sudah memberikan Stimulasi Motorik dengan sangat baik yaitu sebanyak 37 responden $(55,22 \%)$, dan sebanyak 9 responden $(13,43 \%)$ perilaku Stimulasi Motorik orang tua terhadap anaknya cukup.

b. Perkembangan Bahasa Pada Anak Usia 12-36 Bulan

Tabel 2 : Distribusi Frekuensi Perkembangan Bahasa Anak Usia 12-36 Bulan

\begin{tabular}{lcc}
\hline \multicolumn{1}{c}{ Perkembangan Bahasa } & $\boldsymbol{f}$ & $\mathbf{\%}$ \\
\hline Sesuai & 48 & 71,6 \\
Meragukan & 14 & 20,9 \\
Menyimpang & 5 & 7,5 \\
Jumlah & 67 & 100 \\
\hline
\end{tabular}

Berdasarkan tabel diatas didapatkan sebagian besar responden perkembangan bahasa sesuai dengan usia yaitu sebanyak 41 responden $(61,2 \%)$, sedangkan 20 responden $(29,9 \%)$ meragukan dan 6 responden (9\%) menyimpang dalam perkembangan bahasanya. 
c. Hubungan Perilaku Stimulasi Motorik Oleh Orang Tua Dengan Perkembangan Bahasa Anak Usia 12-36 Bulan

Tabel 3: Tabulasi Silang Hubungan Perilaku Stimulasi Motorik Oleh Orang Tua dengan Perkembangan Bahasa Anak Usia 12-36 Bulan

\begin{tabular}{ccccccccc}
\hline \multirow{2}{*}{$\begin{array}{c}\text { Perilaku Stimulasi } \\
\text { Motorik Oleh }\end{array}$} & \multicolumn{9}{c}{ Sesuai } & \multicolumn{3}{c}{ Meragukan } & Menyimpang & \multirow{2}{*}{ Jumlah } \\
\cline { 2 - 7 } & $f$ & $\%$ & $f$ & $\%$ & $f$ & $\%$ & $f$ & $\%$ \\
Orang Tua & 36 & 53,7 & 1 & 1,5 & 0 & 0 & 37 & 100 \\
Sangat Baik & 12 & 17,9 & 9 & 13,4 & 0 & 0 & 21 & 100 \\
Baik & 0 & 0 & 4 & 6,0 & 5 & 7,5 & 9 & 100 \\
Cukup & 0 & 0 & 0 & 0 & 0 & 0 & 0 & 100 \\
Kurang & 48 & 71,6 & 14 & 20,9 & 5 & 7,5 & 67 & 100 \\
Total & & & & & & & & \\
\hline
\end{tabular}

Tabel diatas menunjukkan bahwa didapatkan perkembangan bahasa anak yang sesuai itu didapatkan dari perilaku stimulasi motorik oleh orang tua yang sangat baik sebanyak 36 responden $(53,7 \%)$, perkembangan bahasa yang sesuai dari perilaku stimulasi motorik oleh orang tua yang baik sebanyak 12 responden (17,9\%). Perkembangan bahasa anak yang meragukan itu didapatkan dari perilaku stimulasi motorik oleh orang tua yang baik sebanyak 9 responden $(13,4 \%)$ yang lebih besar daripada perkembangan bahasa yang meragukan dari perilaku stimulasi motorik oleh orang tua yang cukup sebanyak 4 responden $(6,0 \%)$ dan yang baik 1 responden $(1,5 \%)$. Perkembangan bahasa anak yang menyimpang itu didapatkan dari perilaku stimulasi motorik oleh orang tua yang cukup sebanyak 5 responden $(7,5 \%)$ yang lebih besar daripada perkembangan bahasa yang meragukan dan menyimpang dari perilaku Stimulasi Motorik oleh orang tua yang sangat baik dan baik.

Hasil uji korelasi Spearman dengan software komputer didapatkan hasil sebagai berikut.

Tabel 4: Hubungan Perilaku Stimulasi Motorik Oleh Orang Tua dengan Perkembangan Bahasa Anak Usia 12-36 Bulan

\section{Correlations}

\begin{tabular}{|c|c|c|c|c|}
\hline & & & $\begin{array}{c}\text { Perilaku Stimulasi } \\
\text { Motorik oleh orang } \\
\text { tua }\end{array}$ & $\begin{array}{l}\text { Perkembangan bahasa } \\
\text { anak usia } 12-36 \text { bulan }\end{array}$ \\
\hline \multirow{2}{*}{$\begin{array}{ll}\text { Spearman' } \\
\text { s rho }\end{array}$} & $\begin{array}{l}\text { Perilaku } \\
\text { Stimulasi } \\
\text { Motorik oleh } \\
\text { orang tua }\end{array}$ & $\begin{array}{l}\text { Correlation Coefficient } \\
\text { Sig. (2-tailed) } \\
\mathrm{N}\end{array}$ & 1.000 & $\begin{array}{r}.730^{* *} \\
.000 \\
67\end{array}$ \\
\hline & $\begin{array}{l}\text { Perkembangan } \\
\text { bahasa anak } \\
\text { usia 12-36 } \\
\text { bulan }\end{array}$ & $\begin{array}{l}\text { Correlation Coefficient } \\
\text { Sig. (2-tailed) } \\
\mathrm{N}\end{array}$ & $\begin{array}{r}.730^{* *} \\
.000 \\
67\end{array}$ & 1.000 \\
\hline
\end{tabular}

**. Correlation is significant at the 0.01 level (2tailed).

Berdasarkan tabel 4 diatas didapatkan nilai Sig.(2-tailed) didapatkan $(p)=0,000$ dan $r$ $=0,730$ dengan taraf kesalahan dengan $(\alpha) 5 \%=0,05$ yang berarti berarti $\left(\mathrm{H}_{0}\right)$ ditolak dan $\mathrm{H}_{1}$ diterima sehingga memiliki arti ada hubungan antara Perilaku Stimulasi Motorik Oleh Orang Tua Dengan Perkembangan Bahasa Anak Usia 12-36 Bulan. Dengan demikian hubungan keduanya positif dan tingkat hubungannya kuat yang artinya makin baik perilaku Stimulasi Motorik oleh orang tua maka makin sesuai dengan perkembangan bahasa anak usia 12-36 bulan 


\section{Pembahasan}

\section{Perilaku Stimulasi Motorik oleh Orang tua}

Berdasarkan hasil penelitian tentang perilaku Stimulasi Motorik oleh orang tua yang dilakukan di Desa Merjoyo Kecamatan Purwoasri Kabupaten Kediridari 67 responden mayoritas memiliki perilaku Stimulasi Motorik yang sangat baik sebanyak 37 responden $(55,22 \%)$ yang mayoritas berpendidikan SMP sebanyak 26 responden $(38,8 \%)$, usia orang tua yang mayoritas berumur 20-35 tahun sebanyak 40 responden $(59,7 \%)$ dan pekerjaan orang tua yang mayoritas sebagai IRT sebanyak 27 responden $(40,3 \%)$,

Perilaku dipengaruhi oleh pendidikan, umur, dan pekerjaan. Semakin tinggi pendidikan seseorang maka semakin mudah orang tersebut menerima informasi, semakin dewasa seseorang semakin baik pula perilakunya karena tingkat kematangan jiwanya semakin tinggi sehingga semakin mudah menerima informasi. Pendapatan ibu yang memadai akan menunjang tumbuh kembang anak. ${ }^{3}$

Berdasarkan hasil penelitian hubungan perilaku Stimulasi Motorik oleh orang tua dapat diketahui sebagian besar perilakunya sangat baik karena informasi yang cukup baik dari tenaga kesehatan (bidan), saudara ataupun informasi dari buku-buku kesehatan, media elektronik, dan media massa seperti majalah dan TV .

Untuk itu diperlukan kerjasama dari petugas kesehatan, keluarga, lingkungan, media elektronik, dalam pemberian informasi melalui penyuluhan maupun konseling tentang perkembangan bahasa anak usia 12-36 bulan. Dengan demikian orang tua dapat mengetahui perilaku Stimulasi Motorik perkembangan bahasa anak usia 12-36 bulan.

2. Perkembangan Bahasa Pada Anak Usia 12-36 Bulan

Berdasarkan hasil penelitian tentang perkembangan bahasa yang dilakukan di Desa Merjoyo Kecamatan purwoasri Kabupaten Kediri dari 67 responden mayoritas sesuai yaitu sebanyak 48 responden $(71,6 \%)$ yang mayoritas berpendidikan SMP. Hal ini menunjukkan bahwa orang tua yang berpendidikan tinggi dapat menerima informasi dari luar terutama tentang cara pengasuhan anak yang baik, menjaga kesehatan pendidikan yang baik pula dan usia juga mempengaruhi sikap dan pola pikir seseorang karena semakin bertambahnya usia semakin banyak pula pengalaman dan pengetahuan yang sudah di dapat, sehingga lebih peka dalam menstimulasi motorik perkembangan anaknya serta pekerjaan sering menjadi kualitas interaksi anak dengan orang tua. ${ }^{4}$

Faktor penting yang mempengaruhi perkembangan adalah perkembangan otak dan kecerdasan, jenis kelanin anak, kondisi fisik, lingkungan keluarga, kondisi ekonomi, setting sosial/ lingkungan budaya, billingualism ( 2 bahasa). ${ }^{5}$

Berdasarkan hasil penelitian perkembangan bahasa anak usia 12-36 bulan di Desa Merjoyo Kecamatan Purwoasri Kabupaten Kediri diketahui bahwa sebagian memiliki perkembangan bahasa yang sesuai. Maka dari itu peran keluarga, lingkungan tenaga kesehatan atau pun informasi dari buku-buku kesehatan, media elektronik, teman, dan media massa seperti majalah, TV dan internet sangat diperlukan. Peran ibu sangat penting dalam hal perkembangan bahasa usia 12-36 bulan karena orang tua merupakan salah satu faktor yang mempengaruhi perkembangan bahasa seorang anak. Stimulasi Motorik tumbuh kembang anak ini dapat dilakukan oleh setiap orang yang berinteraksi dengan anak, mulai dari ibu, ayah, pengasuh anak, anggota keluarga lain dan kelompok masyarakat di lingkungan rumah tangga masing-masing dan dalam kehidupan sehari-hari

3. Hubungan Perilaku Stimulasi Motorik Oleh Orang Tua Dengan Perkembangan Bahasa Anak Usia 12-36 Bulan .

Berdasarkan hasil penelitian didapatkan perkembangan bahasa yang meragukan dari perilaku stimulasi motorik oleh orang tua yang baik sebanyak 9 responden (13,4\%). Supartini (2014) berpendapat bahwa pendidikan orang tua merupakan salah satu faktor yang mempengaruhi pola asuh disamping faktor lain seperti usia orang tua, keterlibatan ayah, pengalaman sebelumnya dalam mengasuh anak, stress orang tua, dan hubungan antara suami istri. ${ }^{4}$ Ketika orang tua memiliki pengetahuan cukup yang diperoleh dari pendidikan maka pengetahuan dan kemampuan 
orang tua dalam memberikan stimulasi kepada anak dapat terpenuhi. Papalia, Olds \& Feldeman (2013) menyatakan ibu dengan tingkat pendidikan rendah merupakan faktor resiko keterlambatan bahasa pada anak. Cara bagaimana orang tua mengajarkan bahasa dan memberi stimulasi motorik dapat mempengaruhi laju perkembangan bahasa anak. ${ }^{3,6}$ Soetjiningsih \& Ranuh (2014) menyatakan pendidikan orang tua merupakan salah satu faktor yang penting dalam pola asuh dan perkembangan anak. Pendidikan orang tua yang baik dapat menjadikan orang tua mampu menerima segala informasi dari luar termasuk cara mengasuh, menjaga kesehatan, mendidik anak. ${ }^{7}$

Hal ini disebabkan oleh adanya beberapa faktor seperti : pendidikan orang tua yang kurang sehingga perilaku stimulasi motorik orang tua tentang perkembangan bahasa pada anak kurang, pekerjaan ibu yang menyita banyak waktu sehingga ibu tidak begitu memperhatikan perkembangan anaknya, usia ibu yang masih muda sehingga belum mempunyai banyak pengalaman, serta lingkungan sekitar juga berpengaruh terhadap perilaku stimulasi motorik orang tua.

Berdasarkan hasil penelitian dengan menggunakan uji statistik Korelasi Spearman diperoleh besar Korelasi Spearman $=0,730$ dengan uji signifikasi $(p)=0,000$ dan taraf kesalahan $(\alpha) 5 \%=$ 0,05 . Dengan demikian $\mathrm{p}<\alpha$ maka Ho ditolak sedangkan H1 diterima berarti ada hubungan positif (korelasi positif) antara perilaku Stimulasi Motorik oleh orang tua dengan perkembangan bahasa anak usia 12-36 bulan, tingkat hubungan keduanya kuat.

Tingkat perilaku stimulasi motorik yang cukup cenderung memiliki dampak perkembangan bahasa yang menyimpang pada anaknya. Dan semakin tinggi pendidikan, usia lebih matang dan pekerjaan orang tua yang baik, maka makin baik perkembangan bahasa anak. Anak usia $12-36$ bulan aktivitasnya tergantung pada lingkungan keluarga. Lingkungan keluarga merupakan salah satu faktor yang berpengaruh cukup besar bagi perkembangan bahasa anak. Karena di dalam lingkungan anak akan menjalani kesehariannya dengan baik tanpa adanya kesulitan dalam berinteraksi. Stimulusi motorik yang didapat anak melalui lingkungan keluarga akan berpengaruh pada perkembangan bahasa anak. Rangsangan yang diterima secara perlahan akan mempengaruhi perkembangan bahasa anak. Stimulusi motorik dari orang-orang terdekatnya yaitu orang tua (ibu) akan diproses oleh anak sehingga membuat anak tersebut matang dalam berpikir, bertindak, dan berbahasa. Peranan orang tua sangat penting sehingga orang tua perlu untuk selalu waspada serta berhati-hati dalam mengajari anaknya. Orang tua harus memahami tahapan-tahapan perkembangan bahasa pada anak agar dapat memberikan stimulusi motorik pada tahap perkembangan sesuai dengan usia anak.

Oleh karena itu bagi tenaga kesehatan perlunya ikut serta dalam pemantauan perkembangan bahasa anak seperti melakukan pelayanan kesehatan anak dan melakukan skrining dengan menggunakan KPSP di setiap3 bulan pada anak kurang dari 24 bulan dan setiap 6 bulan pada anakanak umur 24-72 bulan serta penilaian ulang KPSP 2 minggu kemudian. Bila tahapan perkembangan terjadi penyimpangan (P), sebaiknya lakukan tindakan rujukan ke Rumah Sakit dengan menuliskan jenis dan jumlah penyimpangan perkembangan yang dialami.

\section{Kesimpulan}

Berdasarkan pembahasan dan analisa yang telah disampaikan dalam bab sebelumnya, maka kesimpulan yang dapat diambil dari penelitian ini adalah: sebagian besar perilaku stimulasi motorik oleh orangtua anak usia 12-36 bulan adalah sangat baik sebanyak 37 responden $(55,2 \%)$. Sebagian besar perkembangan bahasa anak usia $12-36$ bulan adalah sesuai sebanyak 48 responden $(71,6 \%)$. Ada hubungan kuat antara perilaku stimulasi motorik oleh orangtua dengan perkembangan bahasa anak usia 12-36 bulan dengan hasil uji menggunakan Spearman's Rank yang diperoleh dengan uji signifikan (p) $0,000, r=0,730$, semakin baik perilaku stimulasi motorik oleh orang tua maka semakin sesuai dengan perkembangan bahasa anak

\section{Daftar pustaka}

1. Mulyani, S. Perkembangan Psikologi Anak, Yogyakarta: Laras Media Prima. 2013. 
2. Depkes RI. Pedoman Pelaksanaan Stimulasi Motorik, Deteksi dan Intervensi DDTK di Tingkat Pelayanan Kesehatan Dasar, Jakarta. 2016.

3. Ariani, Mardhani Yosoprawoto. Usia Anak dan Pendidikan Ibu sebagai Faktor Risiko Gangguan Perkembangan Anak. Jurnal Kedokteran Brawijaya. Vol 27 No 2.2012. https://jkb.ub.ac.id/index.php/jkb/article/view/116/116

4. Supartini Y. Buku Ajar Konsep Dasar Keperawatan Anak. Jakarta: EGC. 2014.

5. Sumaryanti, Lilis. Peran Lingkungan Terhadap Perkembangan Bahasa Anak.Jurnal Studi $\begin{array}{llllll}\text { Kependidikan dan } & \text { Keislaman. } & \text { Vol } & 7 & \text { No.01. } & 2017 .\end{array}$ http://journal.umpo.ac.id/index.php/muaddib/article/view/552

6. Papalia, D. E., Olds, S. W., \& Feldman, R. D. Human Development (Psikologi Perkembangan Edisi Kesepuluh). Jakarta: Salemba Humanika. 2013.

7. Soetjiningsih, Gde Ranuh IGN. Tumbuh Kembang Anak. Jakarta: EGC. 2015.

8. Notoatmodjo, S . Metodologi Penelitian Kesehatan, Jakarta: Rineka Cipta. 2010.

9. Nursalam. Metodologi Penelitian Ilmu Keperawatan, Jakarta: Salemba Medika. 2008

10.Sugiyono. Statistika Untuk Penelitian, Bandung: Alfabeta. 2009 